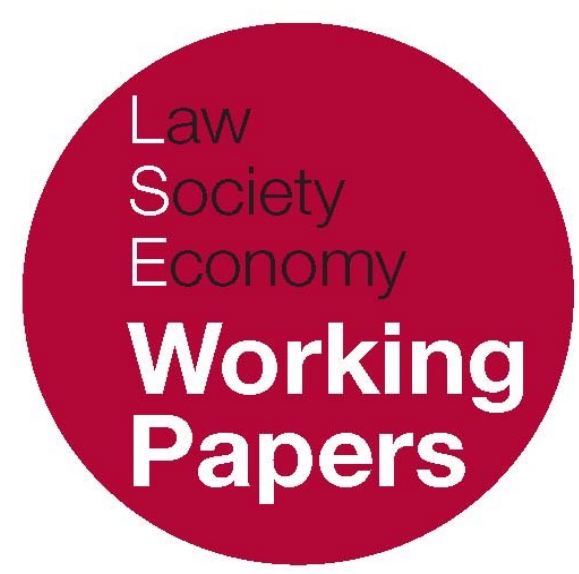

\title{
The Internal and External Constraints of Data Protection on Competition Law in the EU
}

\author{
Francisco Costa-Cabral and Orla Lynskey \\ LSE Law, Society and Economy Working Papers 25/2015 \\ London School of Economics and Political Science \\ Law Department
}

This paper can be downloaded without charge from LSE Law, Society and Economy Working Papers at: www.lse.ac.uk/collections/law/wps/wps.htm and the Social Sciences Research Network electronic library at: http://ssrn.com/abstract $=2703655$.

(C) Francisco Costa-Cabral and Orla Lynskey. Users may download and/or print one copy to facilitate their private study or for non-commercial research. Users may not engage in further distribution of this material or use it for any profit-making activities or any other form of commercial gain. 


\title{
The Internal and External Constraints of Data Protection on Competition Law in the EU
}

\author{
Francisco Costa-Cabral ${ }^{*}$ \\ Orla Lynskey ${ }^{* *}$
}

\begin{abstract}
Personal data has both an economic and a dignitary value. This begs the question of whether competition law should respect the dual nature of personal data, given that the regulation of competition is chiefly dictated by economic concerns. This article addresses that question by mapping the potential intersections between EU data protection law and competition law. In particular, it argues that data protection law exercises an internal and an external constraint on competition law. On the one hand, competition law involves judgments about 'normal competition' and consumer welfare which may require a normative contribution by data protection law. Using data protection as a normative benchmark in this way does not depart from the logic of competition law as data protection still requires a competitive concern hook on which to hang. Data protection would thus act as an 'internal constraint' on competition law. On the other hand, regardless of such logic, competition authorities are bound to respect the fundamental right to data protection. This requires them to restrict the scope of competition law and to guarantee the effectiveness of that fundamental right. In this way, data protection acts as an 'external constraint' on competition law. Recognising these constraints would pave the way for a more coherent EU law approach to consumer concerns in a digital society.
\end{abstract}

\footnotetext{
* Assistant Professor, China-EU Law School (CESL) at the China University of Political Science and Law.

** Assistant Professor, LSE Law Department. E-mail: o.lynskey@lse.ac.uk. Feedback and comments on this working paper are welcome.
} 


\section{INTRODUCTION}

Personal data has been described as 'the oil of the information economy'. ${ }^{1}$ This analogy reflects the economic value of personal data in the digital economy but fails to capture that, unlike oil, personal data is intrinsically linked to the dignity, autonomy, and privacy of individuals. ${ }^{2}$ The dual nature of personal data is nonetheless now recognised, leading to the inclusion of a right to data protection in the European Union Charter of Fundamental Rights (the Charter). ${ }^{3}$ Indeed, the challenges that personal data's duality poses for the regulation of personal data processing are evidenced by the protracted debate over the new legislative framework for data protection in the European Union (EU). ${ }^{4}$ It also begs the question of whether the dual nature of personal data should also be reflected by in EU competition law, given that the regulation of competition is chiefly dictated by economic concerns. This article addresses that question by mapping the potential intersections between EU data protection law and competition law. In particular, it identifies how data protection law may influence the application of competition law by the Commission.

While competition is a well-established area of EU law and policy, the EU only first developed a data protection framework in $1995^{5}$ and this framework has, to date, been under-enforced. This may explain why little attention has been paid to the relationship between the two fields. Naturally, the growing importance of personal data for economic activity has been noted by competition law scholars. This is particularly so in the US, although the burgeoning literature there is of limited relevance in the EU context given the distinct legal framework and institutional arrangements in the EU. From an EU perspective, substantive data

\footnotetext{
1 See, for instance, the keynote speech of former Commissioner Kuneva, 'Keynote Speech: Roundtable on Online Data Collection, Targeting and Profiling, Brussels, 31 March 2009, SPEECH/09/156, or Patrick Moorhead, 'Why your Personal Data is the New Oil', AdAge, 10 November 2011 (http://adage.com/article/digitalnext/personal-data-oil/230932/).

2 A better analogy for personal data in a digital economy might be peasant work in agrarian economies, since its value is also essential but diffused throughout the society and often without being recognised a personal dimension.

3 Charter of Fundamental Rights of the European Union [2000] OJ C364/01 and [2010] OJ C83/389.

4 The European Commission proposed a new data protection regulation in January 2012. (European Commission, Proposal for a Regulation of the European Parliament and of the Council on the protection of individuals with regard to the processing of personal data and on the free movement of such data (General Data Protection Regulation) COM(2012) 11 final.) Agreement was reached on the final text of this regulation almost 4 years later in December 2015 (European Commission, 'Agreement on Commission's EU data protection reform will boost Digital Single Market', IP/12/46).

5 European Parliament and Council Directive 95/46/EC of 24 October 1995 on the protection of individuals with regard to the processing of personal data and on the free movement of such data [1995] OJ L281/23.
} 
protection concerns have been dismissed by competition law practitioners and scholars as simply another 'non-economic' interest standing outside competition law's analytical methods and policy goals. ${ }^{6}$ In support of this claim, references are made to the judgment of the Court of Justice of the EU (the Court) in AsnefEquifax ${ }^{7}$, as well as the Commission decision in the Facebook/Whats App $p^{8}$ merger, where a concurrent application of the two regimes was suggested.

The influence of data protection (and other fundamental rights) on competition law has thus been confined to ensuring respect for certain procedural guarantees during the investigation of competitive infringements. ${ }^{9}$ To the extent that competition law must consider markets in which personal data is present, competition scholars argue that personal data should be analysed according to its economic characteristics, like any other good or service. In this regard, data protection regulation would merely set the 'legal context' in which competitive relationships unfold, and would be no different from other market regulation. For their part, data protection advocates have focused on developing the guiding principles of their nascent field of law, and have dedicated little attention to its interaction with the areas of EU law that preceded it. As shall be outlined below, some commonality of goals can be identified between competition and data protection law, most evidently the promotion of consumer interests, leading to calls by the European Data Protection Supervisor (EDPS) for greater cooperation between the respective regulators. ${ }^{10}$ Nevertheless, this also places data protection amongst the many policy areas which authors claim should be taken into account by competition law under a wide notion of 'consumer welfare' - calls which thus far remain unheeded. ${ }^{11}$

This article argues that competition law allows for influence by data protection norms. In particular, it proposes that EU data protection norms may impose both an internal and an external constraint on the application of competition law. Data protection norms can exercise an 'internal' constraint when the substantive assessments undertaken pursuant to competition law integrate data

\footnotetext{
${ }^{6}$ See, for instance, Richard Craig, 'Big Data and competition - merger control is not the remedy for data protection issues', July 2014. Last accessed 3 November 2015, available at: http://unitedkingdom.taylorwessing.com/globaldatahub/article_big_data_competition.html .

${ }^{7}$ C-238/05, Asnef-Equifax, Servicios de Información sobre Solvencia y Crédito, SL v Asociación de

Usuarios de Servicios Bancarios (Ausbanc) [2006] ECR I-11125.

8 Facebook/ WhatsApp (Case COMP/M.7217) Commission Decision [2014] OJ C 417/02.

9 See, for instance, Damien Geradin and Monica Kuschewsky, 'Competition Law and Personal Data: Preliminary Thoughts on a Complex Issue’ (2013), available at SSRN:

http://dx.doi.org/10.2139/ssrn.2216088.

10 Preliminary Opinion of the European Data Protection Supervisor, 'Privacy and competitiveness in the age of big data: The interplay between data protection, competition law and consumer protection in the Digital Economy', March 2014.

11 See, for instance, Chris Townley, Article 81 EC and Public Policy (Hart, 2009). This does not mean that public policy is not effectively taken into account, only that it is has not expressly been under a wide notion of consumer welfare.
} 
protection considerations and thus, for instance, data protection considerations determine whether competition is harmed in markets for, or dependent upon, personal data. Data protection norms can exercise an 'external' constraint on competition law when the Commission is under an obligation to take them into consideration due to their relative weight vis-à-vis competition law and other policy areas. For example, the procedural guarantees resulting from data protection constitute an external constraint which conditions the investigation of alleged competition law infringements. Internal constraints would thus fit within the pre-established legal confines of competition law, while external constraints would override them.

This article shall proceed as follows. Firstly, it sets out relevant aspects of competition and data protection law in part two and briefly highlights the common ground shared by both policies. Part three focuses on how data protection norms can be incorporated into the analytical framework of competition law, notably the existing notion of consumer welfare, and thus exert an internal constraint on it. Part four considers whether, beyond this fixed framework, aspects of data protection can influence how competition law and policy is applied, and thus exercise an external constraint on competition law. The discussion on the intersection of data protection and competition law is not of interest only to the initiated. This issue exposes fundamental tensions regarding the role of personal data in the information society, which go beyond the traditional confines of competition or data protection law. It also provides an opportunity to observe how the changes to the legal and institutional framework brought about the Lisbon Treaty might affect the pre-existing normative coherence of different areas of EU law. In this regard, data protection provides an excellent case study for consideration of how the EU will integrate the demands of fundamental rights protection with its existing enforcement of other policies.

\section{COMPETITION AND DATA PROTECTION LAW IN THE EU}

While a detailed description of the legal framework for competition law and data protection in the EU is beyond the scope of this article, it is necessary to outline their key features (2.1. and 2.2.) and their common characteristics in order to understand how the two legal regimes potentially intersect (2.3.). The ancillary role of data in the competitive process must also be differentiated from situations when personal data itself is the object of competition, in particular as regards competition for the acquisition of personal data (2.4.). 


\subsection{The Legal Framework Applicable to Personal Data Processing}

Personal data processing in the EU has been regulated for almost two decades, with the original Data Protection Directive undergoing its first legislative overhaul at present. Once complete, the Directive shall be replaced by a General Data Protection Regulation (GDPR). Despite the lengthy legislative process to enact the GDPR, the structure of the legal framework applicable to personal data processing will remain largely unchanged. Three key features of this framework are noteworthy. First, data protection law in the EU has a broad scope of application as a result of the expansive definition of terms such as 'personal data' and 'processing'. Personal data is defined as 'any information relating to an identified or identifiable person' while processing encompasses 'any operation or set of operations which is performed upon personal data, whether or not by automatic means'.12 The Court has consistently supported the broad scope of application of the data protection regime. For instance, in Google Spain ${ }^{13}$, despite the Advocate General's reservations regarding the Directive's broad scope, the Court adopted a literal - and expansive - interpretation of 'processing' in order to ensure the Directive would not be deprived of its effect. ${ }^{14}$ The data protection regime does not therefore merely apply to the use or misuse of personal data, the mere act of collecting personal data in the first instance is regulated by this framework.

A second key feature of the regime is that, despite the misgivings expressed regarding its broad scope, once within its scope personal data processing is not necessarily prohibited. This is clear from cases such as Rynes ${ }^{15}$, where the Court interpreted the scope of an exemption to the data protection rules narrowly but explicitly indicated that the personal data processing was likely to be legitimate once assessed pursuant to the data protection framework. The data protection framework could therefore be said to legitimise personal data processing. ${ }^{16}$ Such processing is permissible provided it, first, has a legal basis and, second, complies with the safeguards set out in secondary legislation. Of the potential legal bases

\footnotetext{
12 Directive 95/46 EC (n5) Art 2(a) and (b).

${ }_{13}$ Case C-131/12 Google Spain SL and Google Inc. v Agencia Española de Protección de Datos

(AEPD) and Mario Costeja González. ECLI:EU:C:2014:317.

14 ibid, [29]

${ }^{15}$ Case C-212/13 František Ryně̌ ECLI:EU:C:2014:2428.

${ }^{16}$ It should be noted that this regime has been classified as 'prohibitive' by the UK's Information Commissioner's Office (ICO) insofar as personal data processing is prohibited unless it is established that it falls within a particular 'gateway'. ICO, 'Information Commissioner's Office: Initial Analysis of the European Commission's Proposals for a Revised Data Protection Legislative Framework', 27 February 2012, 9. This document has been removed from the ICO website:

$<$ https://wiki.laquadrature.net/images/1/12/Ico_initial_analysis_of_revised_eu_dp_legislative_proposal s.pdf> accessed 3 March 2015.
} 
listed, the most frequently cited is the consent of the individual 'data subject'. ${ }^{17}$ However personal data processing can also rely on other legal bases in order to be lawful. For instance, processing is legitimate if it is necessary for compliance with a legal obligation or for the performance of a contract. Much data processing conducted online therefore relies not on consent but on a catch-all legal basis whereby processing is legitimate provided that it is 'necessary for the purposes of the legitimate interests pursued by the data controller or by a third party or parties to whom the data are disclosed, except where such interests are overridden by the interests or fundamental rights and freedoms of the data subject'.18 In addition to having a legal basis for data processing, a number of safeguards for personal data processing must also be complied with in order for data processing to be legitimate. For instance, personal data must be processed 'fairly and lawfully'19 and be 'adequate, relevant and not excessive in relation to the purposes for which they are collected and/or further processed'. ${ }^{20}$ Provided these criteria are respected, personal data processing is permitted.

Through this framework, data protection legislation functions as a system of checks and balances which determines the boundary between permissible and impermissible personal data processing and, in so doing, reconciles individual rights and other societal interests. Nevertheless, the third key feature of the data protection regime is that it is a rights-based framework. This is evident in two ways. First, the data protection regime grants individuals subjective rights over their personal data, for instance, the right to information regarding the processing of their personal data ${ }^{21}$, the right to delete personal data in certain circumstances ${ }^{22}$ and the right to access personal data. ${ }^{23}$ Secondly, the legislative framework was bolstered by the Charter, Article 8 of which sets out a right to data protection in addition to the right to privacy set out in Article 7, thereby consolidating the role of individual rights at the heart of the EU data protection law regime.

\subsection{The Legal Framework Applicable to the Competitive Process}

Competition law is concerned with preserving the competitive process, under the assumption that this process is the most efficient way to promote consumer welfare, guarantee economic freedom and achieve market integration. These goals cannot be achieved through competition law alone - for example, market integration is the focus of much of EU law. Competition law plays its part in

\footnotetext{
17 Directive 95/46 EC (n5) Art 7(a).

18 ibid, Art 7(f).

19 ibid, Art 6(1)(a).

20 ibid, Art 6(1)(c).

21 ibid, Arts 10 and 11.

22 ibid, Art 12(b).

23 ibid, Art 12(a).
} 
achieving these goals by focusing on economic activity and making sure that the agents of this activity - 'undertakings' - do not harm competition. Roughly speaking, competition law approaches the problem of establishing harm to competition in two stages. First, it identifies certain actions which might raise competitive concerns. Secondly, it applies tailored tests to these actions depending upon the particular concern at issue. These two stages are primarily governed by open-textured, negatively-framed Treaty provisions.

The first of these provisions, Article 101 TFEU, prohibits collusion between undertakings ('agreements', 'concerted practices' and 'decisions by associations of undertakings') which have as their 'object or effect' the restriction of competition. According to the Court, restrictions by object are those 'that can be regarded, by their very nature, as being harmful to the proper functioning of normal competition'. ${ }^{24}$ This definition points to an essential normative incompatibility between the conduct concerned and the goals of competition law, which is assessed by judging the objectives pursued by undertakings in their economic and legal context. The most notable example is undertakings agreeing to abstain from competing between themselves by fixing prices or sharing markets through 'cartels'. ${ }^{25}$ However, as discussed below, other restrictions by object involve a more detailed analysis of what constitutes a departure from 'normal competition'. In contrast, restrictions by effect are based on negative effects on competition. ${ }^{26}$ Whether such effects result, or are likely to result, from particular conduct is a factual assessment also based on the economic and legal context in which the undertakings operate.

The second provision is Article 102 TFEU, which prohibits the 'abuse' by an undertaking of its 'dominant position'. A dominant position has been defined as the ability to behave independently of competitors and consumers, and is presumed when an undertaking has a market share of over $50 \%$ in a relevant market. ${ }^{27}$ Market share is an indication of the market power of an undertaking, and this market power in turn may depend on the existence of market barriers that confer a competitive advantage on the undertaking and are hard to replicate by competitors. It is substantial market power which makes the actions of dominant undertakings potentially more harmful for competition than those of nondominant undertakings, hence the 'special responsibility' imposed by the case law on dominant undertakings. ${ }^{28}$ In practice, this means that while achieving a dominant position is not prohibited, some actions that would otherwise be permissible will be prohibited. Those actions have been identified by the case law as specific abuses, which are usually grouped around two main competitive concerns: exclusion and exploitation. Exclusion refers to harm to competitors

\footnotetext{
${ }^{24}$ Case C-67/13 Groupement des cartes bancaires (CB) v European Commission ECLI:EU:C:2014:2204, [50].

$25 \mathrm{ibid},[51]$.

${ }^{26}$ Case C-382/12 MasterCard Inc. and Others v European Commission [2014] ECR nyr [93].

27 Case C-62/86 AKZO Chemie BV v Commission [1991] ECR I-3359 [60].

${ }^{28}$ Case C-209/10 Post Danmark A/S v Konkurrencerådet [2012] ECR I-0000.
} 
which does not arise through 'competition on the merits', such as exit from the market or stunted development. ${ }^{29}$ Exploitation refers to harm to consumers, such as charging excessive prices or imposing unfair conditions. Tests to identify such abuses have been set out in the jurisprudence of the Court, and it is common for behaviour to be considered abusive on several counts.

Merger control is an additional concern of competition policy. This is regulated by the EU Merger Regulation (EUMR), which applies to concentrations: mergers and other ways of acquiring control over undertakings. Concentrations beyond certain thresholds are notified to the Commission, which can prohibit them (or impose conditions) if they 'significantly impede effective competition'. ${ }^{30}$ The test set out in the EUMR is whether the concentration may, 'in particular', result in 'the creation or strengthening of a dominant position'. ${ }^{31}$ This reflects the origin of merger control as an abuse under Article 102 TFEU concerned with the exclusion of competitors through their acquisition and the consequent creation of exploitable market power - a rationale that still remains. ${ }^{32}$ However, merger control is now centred on prospective effects to the structure of the market, which are estimated by the Commission by defining the relevant markets and analysing the removal of competitive constraints on the merged entity. ${ }^{33}$

It should be noted that the competition law provisions do not provide the Commission with a general competence to regulate or shape particular markets. Yet, the exercise of the Commission's competences may have such an effect, particularly if undertakings avoid an enforcement decision by offering commitments to remedy an alleged violation of Article 101 or 102 TFEU, or agree to criteria set out by the Commission in order to ensure that a notified merger is given clearance. Neither does the TFEU provide the Commission with particular guidance on the exercise of its competences on competition, which has led to the gradual emergence of 'consumer welfare' as the focus its enforcement. This enforcement shall, according to the Commission, seek to deliver direct benefits to consumers such as 'lower prices, better quality and a wider choice of new or improved goods and services'. ${ }^{34}$ The Court has acknowledged the benefits of

\footnotetext{
29 The Court has stated that 'competition on the merits' does not prevent the exclusion of less efficient undertakings, insofar as these undertakings provide a less attractive to consumers in terms of price, quality, choice and innovation.

${ }^{30}$ Council Regulation (EC) No 139/2004 of 20 January 2004 on the control of concentrations between undertakings (the EC Merger Regulation) [2004] OJ L24/1, Art 2(3).

31 Ibid.

32 Case C-6/72 Continental Can v Commission [1973] ECR 215.

33 This paper will concentrate on non-coordinated effects: Guidelines on the assessment of horizontal mergers under the Council Regulation on the control of concentrations between undertakings [2004] OJ C31/5 [22-38].

${ }^{34}$ See, for instance, Communication, Guidance on the Commission's enforcement priorities in applying Article 82 of the EC Treaty to abusive exclusionary conduct by dominant undertakings [2009] C45/7, 5 .
} 
applying competition law to achieve consumer welfare (defined in this way), but has refused to give the consumer welfare standard priority over other goals of competition law, such as the protection of competition itself and market integration. ${ }^{35}$ It will be seen below that the formulation of consumer welfare by the Court and the Commission is particularly important for present purposes.

\subsection{Common Characteristics of Data Protection and Competition LaW}

The reform of the EU data protection framework has provided an opportunity for the data protection community to look to other legal frameworks for inspiration. It has been noted that data protection has much to learn from the elaborate procedural framework for the enforcement of Competition law, and suggested that the coherence of the EU legal order requires similar sanctions for data protection law as those administered by competition authorities. ${ }^{36}$ However, beyond this potential for procedural convergence, the two legal regimes appear to have little in common from a substantive perspective. The only evident point of convergence is that both data protection and competition law pursue market integration as an objective. The enactment of the Data Protection Directive was premised on Article 114 TFEU (ex Article 100a EC), a provision which allows the EU legislature to adopt measures to approximate national laws provided they have as their objective the 'establishment and functioning of the internal market'.37 Data protection legislation is therefore an instrument of positive integration as it introduced data protection legislation in Member States where there was none and, in its capacity as an instrument of maximum harmonisation ${ }^{38}$, minimised the divergences between existing legislation in other Member States. ${ }^{39}$ Similarly, competition law seeks to achieve market integration, albeit through negative integration, by ensuring that undertakings do not partition the market through mechanisms such as territorial allocation, restrictions on exports or on parallel trade. ${ }^{40}$

Another commonality of data protection and competition law is that both share a concern for the consumer. In addition to the objective of ensuring the free

\footnotetext{
35 See, for instance, C501/06 GlaxoSmithKline Services Ltd v Commission [2009] ECR I-09291, or Case C8/08, T-Mobile [2009] ECR I-04529.

36 See, D Kloza and A Moscibroda, 'Making the case for enhanced enforcement cooperation between data protection authorities: insights from competition law' (2014) 4(2) International Data Privacy Law 120.

37 The Directive's explanatory memorandum identified cross-border data flows for business purposes as one of several areas in which the free flow of personal data between EU Member States was necessary. Commission Communication on the protection of individuals in relation to the processing of personal data in the Community and Information Security $\operatorname{COM}(90) 314$ final, 16.

38 Asnef-Equifax (n7).

39 For a comprehensive overview of the use of negative integration in the Internal Market, see Catherine Barnard, The Substantive Law of the EU: The Four Freedoms (4th edn, OUP, 2013).

40 This is a long-standing objective. See, Joined Cases 56 and 58/64 Consten and Grundig-Verkaufs v. Commission [1966] ECR 299.
} 
flow of personal data between Member States, data protection seeks to 'protect the fundamental rights and freedoms of natural persons, and in particular their right to privacy'. ${ }^{41}$ This emphasis on individual rights has been reinforced by the inclusion of a fundamental right to data protection in the Charter while the Commission's preference for 'consumer welfare' as an enforcement priority also places individuals at the heart of the competition law regime. ${ }^{42}$ This shared concern prompted calls by the EDPS for convergence in the application of the two regimes. ${ }^{43}$ However, as consumer protection law is distinguished from competition law, and data protection is often treated as a subset of consumer protection law, the two can also be distinguished in this regard. For instance, Ohlhausen and Okuliar suggest that the substantive concerns of both are distinct 44 : they argue that 'antitrust laws are focused on broader macroeconomic harms, mainly the maintenance of efficient price discovery in markets, whereas the consumer protection laws are preoccupied with ensuring the integrity of each specific contractual bargain'. ${ }^{45}$ Or, as Averitt and Lande put it, antitrust caters for the availability of consumer choice while consumer law provides consumers with the relevant information for the effective exercise of this choice. ${ }^{46}$ From this perspective, data protection and competition law intervene to influence market conduct at different levels of the same spectrum. ${ }^{47}$ Competition law applies to correct market failures that are external to the individual, such as reduced choice and increased prices, while data protection law applies to correct internal failings, such as information and power asymmetries. ${ }^{48}$ The fact that market failures can

\footnotetext{
${ }^{41}$ Directive 95/46 (n5) Art 1(1).

42 As shall be discussed below, the Court has refused to allow this economic, consumer-based standard to prevail over Competition law's market integration objective.

43 Preliminary Opinion of the EDPS (n10) [6].

44 Indeed, although competition and consumer protection enforcement both fall under the auspices of the FTC in the United States (US), it has been argued that there are institutional impediments to their converged enforcement. See further, Maureen K Ohlhausen and Alexander Okuliar, 'Competition, Consumer Protection, and the Right (Approach) to Privacy' (February 6, 2015). Available at SSRN: http: $/ /$ ssrn.com/abstract $=2561563$.

45 ibid, 39.

46 Averitt and Lande, 'Using the "consumer choice" approach to antitrust law' (2007) 74 Antitrust Law Journal 176.

47 On the intersection of competition law and data protection law see Albertina Albors-Llorens, 'Competition and Consumer Law in the European Union: Evolution and Convergence' (2014) Yearbook of European Law 1.

48 The EDPS has stated, to the contrary, that 'refusal of access to personal information and opaque or misleading privacy policies may justify a new concept of consumer harm for competition enforcement in digital economy'. Preliminary Opinion of the EDPS (n10) [26]. Nonetheless, as developed below, the influence of data protection on competition law can operate without a reworking of the notion of consumer welfare.
} 
also result from a power asymmetry - the market power held by some undertakings - is another possible source of shared concerns.

\subsection{The Role of Personal Data in the Competitive Process}

The competitive process is, and always has been, driven by data: market decisions require information about prices of goods and services, input availability, competitor reactions and consumer preferences. The digital revolution has altered the scale of such data gathering and treatment, and the ease with which it can be undertaken. Personal data can therefore support competition in goods or services in a typical ancillary role. The most relevant example is consumer preferences: data about the needs and tastes attributable to individual consumers (or data from which these needs and tastes can be inferred) may enhance competition for certain goods or services. ${ }^{49}$ Another example of this ancillary role is how data regarding the creditworthiness of individuals would constitute personal data processing relevant for the provision of financial services, such as lending. ${ }^{50}$ However, in addition to this ancillary role, personal data can also be a commodity: a good in itself, for which there is supply and demand. The commodification of personal data is one of the defining characteristics of the 'digital revolution'. Without personal data as an input some goods and services are now ostensibly impossible to produce, leading to the growth of commodity markets for personal data. Thus, personal data is a full-fledged factor of production in a modern economy. When considering personal data as a commodity, it is useful to keep two of its alleged attributes in mind: its value is context-dependent, and its value may increase in a non-linear fashion up to a certain tipping point once aggregated (because data linking leads to additional insights).

Two potential conclusions follow regarding the role of personal data in the competitive process. First, as a commodity, personal data can, like any other goods or services, be the object of the competitive process: undertakings compete to acquire and sell personal data. Secondly, as an input, personal data can constitute a barrier to market entry: undertakings may not be able to replicate or acquire the personal data necessary to compete. ${ }^{51}$ Nevertheless, it has been argued that personal data should not be treated as a market barrier. In support of this proposition, it is argued that, given its non-rivalrous nature personal data can be held or used by many simultaneously without losing its value. It is also argued that individuals tend to 'multi-home' online using several data-collecting applications simultaneously for distinct purposes. In theory therefore, a market barrier could

\footnotetext{
${ }^{49}$ It should also be noted that consumers can themselves be undertakings, for example distributors in a supply chain. Article 101 TFEU does not apply to agreements with final consumers, but abuses under Article 102 TFEU are not likewise limited.

50 Asnef-Equifax (n7).

${ }^{51}$ For instance, the Financial Times removed its application from the app store as it needed direct access to consumers in order to monetise its content.
} 
be overcome by attracting consumers to acquire data from them directly, or by purchasing personal data as a commodity on secondary markets. It is nonetheless important to bear in mind that data protection limits how undertakings handle data. Therefore, any trading of personal data must take into consideration that a legal basis is needed for this transfer and for the subsequent processing (this may, for instance, require the renewed consent of the individual). ${ }^{52}$ Whether there is a market for personal data as a commodity or personal data acts as a market barrier for producing other goods and services is part of the definition of the relevant market(s) using standard economic methods.

The value of personal data puts undertakings that have direct access to individuals in a key position in the digital economy, as they can gather personal data directly from them. The analogy of personal data with oil, although flawed, fully applies to the economic value of the extractive procedure. The OECD has recognised that access to customers is critical in so-called data ecosystems. Therefore, the competitive process for data acquisition deserves special attention. Often, a service will be offered for free-at-the-point-of-access (or against a token payment) with the user agreeing to have his or her personal data processed by the service provider. The service provider then uses this personal data to profile the individual and sell targeted advertising opportunities to third parties. This is an example of a 'two-sided market', where positive network effects are provided across the sides involved: the greater the number of users that disclose their personal data, the more the undertaking will be able to monetise it. It can also be argued, more doubtfully, that there is a positive effect in the reverse direction: the more advertising sold, the better the free services provided. ${ }^{53}$

This business model leads to competition for the acquisition of personal data (in the form of more users), which prompts the question: what factors are relevant to how undertakings compete in these markets? As services are provided for freeat-the-point-of-access, the traditional tools of market definition based on price competition are difficult to apply. Therefore, these markets have been defined based on the functionalities of the services offered - which are implicitly assumed to depend on the revenues from the advertising-side, so that relevant competition would happen in relation to this advertising-side. ${ }^{54}$ This approach does not fully incorporate the preferences of the user, notably the concern for data protection and privacy. ${ }^{55}$ The side of the market for the acquisition of personal data can

\footnotetext{
52 It has been suggested by the EDPS that consent is limited to the relevant market. However, consent should not be dependent on the external factors which condition market definition or on the notion of undertaking.

53 This is not necessarily reflected on all the users: some users may withhold their personal data and still benefit from the services.

${ }^{54}$ Facebook/Whats App (n8) [88] and [147].

55 There may also be a negative network effect at work in these double-sided markets: the more data is monetised (for instance, by receiving more personalised advertising), the more reluctant he and she may
} 
therefore be defined, on the demand-side, based on what undertakings are willing to offer for such data: both the positive (the free service) and the potentially negative (the monetisation).

It follows that several factors influence how undertakings compete for the acquisition of personal data, including the service offered and the conditions for the treatment of personal data - what shall be called the undertaking's data use policy. There is no fixed relationship between these factors. Users may only care about the service provided, ignoring whether and how their personal data is treated. In that case, there is only competition on the service. Conversely, the data use policy - encompassing factors such as the quantity and nature of the personal data processed and the uses to which that data is put - may influence users as much or more than the service provided. In that situation, there is competition on data use policy: the undertaking that offers the best policy will attract the most users. 56

Users may also be sensitive to these factors to different extents. ${ }^{57}$ For instance, users may be wary of the treatment of their data but reluctant to switch provider and lose the benefits of a large user base. ${ }^{58}$ To what extent undertakings compete on the basis of their data use policies is an empirical question tackled by market definition. Nevertheless, concerns about the treatment of personal data will rarely be completely absent. Users are not required to have perfect knowledge of that treatment for such concerns to be influential, as most real markets are subject to information asymmetries and biases - indeed, expressing a preference for privacy might itself be a behavioural bias. ${ }^{59}$ This is the so-called 'privacy paradox': while many users express concerns about privacy, few actually act on them. ${ }^{60}$ Nevertheless, from a competitive point of view, those few are enough for significant competition to exist. All that is necessary to form a separate market defined by competition on data use policy is to be able to differentiate concerned

be to disclose personal data. The possibility of such negative effects being meaningful is heavily dependent on the consumer being aware of the monetisation and being able to act by changing providers, which will of course vary according to the market.

56 There can be similar competition for the acquisition of any good or service, not just personal data: for example, companies compete to attract the best professionals through their work policies, enticing them with career development and pay packages.

${ }^{57}$ Market definition in this context may also be difficult, since it is a static exercise that is based on a snapshot of the current usage of personal data while personal data is constantly being put to new uses, which may be both more innovate and more intrusive for individuals.

${ }^{58}$ Stickiness is one of many factors, including network effects, which can enable a provider to achieve scale. See further, Chris Hoofnagle and Jan Whittington, 'Free Accounting for the Costs of the Internet's Most Popular Price' (2014) 61 UCLA Law Review 606.

${ }^{59}$ Humphreys remarked that privacy concerns may be a reaction against feelings of 'invasive monitoring' due to the data immersion on contemporary life. Stephen Humphreys, 'Conscience in the datasphere', LSE Working Papers 11/2015. Available at SSRN: http://ssrn.com/abstract=2613310.

${ }^{60}$ See, for instance, I Cofone, 'The Value of Privacy: Keep the Money Where the Mouth Is', RILE Working Paper Series No 2014/15. Available at SSRN: http://ssrn.com/abstract=2541214. 
users from the others - and, by definition, the data subjects are identified or identifiable. ${ }^{61}$ Even if such a market does not presently exist due to the reluctance of undertakings to engage in competition on data use policy, potential consumer demand would also be enough. ${ }^{62}$

\section{DATA PROTECTION AS AN INTERNAL CONSTRAINT ON COMPETITION LAW}

Personal data can be the object of the competitive process, as a commodity, or it can influence competition for other goods or services. Competition law therefore applies to personal data when it is used or traded as an input or commodity. Thus far, it has been generally assumed that competition law would apply in the same way as it would to any other input or commodity and that data protection rules would not influence this assessment. In Asnef-Equifax, the Court was asked to consider whether an exchange of information between banks about potential bank borrowers was restrictive of competition. In finding that there was no restriction, the Court made its clearest statement yet regarding the interaction between competition law and data protection law. It declared that 'any possible issues relating to the sensitivity of personal data are not, as such, a matter for competition law, they may be resolved on the basis of the relevant provisions governing data protection'. ${ }^{63}$ Similarly, in Google/Doubleclicker, the Commission examined the competitive implications of Google's acquisition of Doubleclick, a company specialising in the delivery of third party advertising solutions, including the competitive implications of combining Google and Doubleclick's existing datasets. The Commission explicitly noted that its decision 'refers exclusively to the appraisal of this operation with Community rules on competition'. ${ }^{65}$ Thus, the Commission appears to exclude data protection considerations from competition law assessments in the context of ex ante merger control while the Court has ostensibly excluded such considerations from the ex post assessment of a suspected infringement of Article 101 TFEU.

Data protection law therefore seems to provide no normative guidance for competition law assessments. While competition law must take account of data protection legislation to the extent that it provides the relevant legal context in markets for personal data, this is merely descriptive of competitive conditions.

${ }^{61}$ Commission Notice on the definition of relevant market for the purposes of Community competition law Privacy enhancing technologies are another way to identify consumers concerned with privacy.

62 Case C418/01, IMS Health v NDC Health [2004] ECR I-5039.

63 Asnef-Equifax (n7) [63].

${ }^{64}$ Case COMP/M.4731 Google/DoubleClick.

65 Ibid, 368. 
When it comes to substantive assessments, whether there is also an infringement of the data protection regime appears to be irrelevant. Data protection issues are therefore ostensibly to be settled concurrently to competition law issues, with the two legal regimes running in parallel. For instance, in Asnef-Equifax the Court noted that the data-sharing arrangement appeared to satisfy the requirements of national data protection legislation. ${ }^{66}$ The Commission also remarked in Google/Doubleclick that its decision was 'without prejudice to the obligations imposed onto the parties by Community [data protection] legislation'. ${ }^{67} \mathrm{Had}$ undertakings on these occasions failed to observe such obligations, it seems that this would have been a question (or problem) of data protection law rather than an issue that could influence the competition law assessment.

In this article, it is suggested that the boundaries between data protection and competition law are not so impervious, and that there are circumstances in which data protection can provide a relevant normative benchmark for competition law. This normative influence can be distinguished from situations where competition law achieves objectives which data protection law would look favourably upon, such as preventing discrimination facilitated by personal data processing or controlling market power which could be leveraged to extract consent for personal data processing. In such situations, there is no need for data protection's normative influence: these objectives can be achieved by applying methods already used by competition law. This normative influence can also be distinguished from situations where, using the reasoning of the Wouters case law, data protection considerations could exempt what would otherwise constitute a restriction of competition under Article 101 TFEU. The role of data protection in such a situation would be to preclude the ordinary application of competition law, explored below as an external constraint, rather than to act as a normative benchmark for its interpretation.

This section will be dedicated to internal constraints: situations where data protection could influence a substantive assessment by interacting with competition law's own normative values. Contrary to indications that the application of the two regimes is separate and concurrent, it is argued that data protection can contribute to the identification and resolution of competitive concerns. While the two regimes might apply concurrently, they may not always do so separately: competition law may internalise a normative judgment originating in data protection, regardless of the consequences under the data protection regime. 68 As shall be seen, competition law has already made infringements of Articles 101 and 102 TFEU dependent on assessments pursuant to other fields of law. It is important to recall that data protection and competition

\footnotetext{
66 Asnef-Equifax (n7) 63.

${ }^{67}$ Google/Doubleclick (n64) 368.

68 In this regard, concurrent application would facilitate the internalisation described below insofar as there would be no precedence of other values over data protection, as it happens when an issue affects internal market and competition. Case C-415/93, Bosman [1995] ECR I-04921
} 
law share important concerns about market integration, consumer welfare and power asymmetries. Thus, if there are circumstances when data protection can point to obstacles to market integration, or help to identify consumer mistreatment or coercion, competition law might listen.

This shall be illustrated with reference to competition on the quality of data use policies. The EDPS has referred to a similar notion: fostering privacy as a competitive advantage. ${ }^{69}$ It will be argued (more broadly) that when the conditions for the treatment of personal data are a competitive parameter, the data protection regime might provide a normative yardstick for assessments of quality.

When competition is touted as a way to promote consumer welfare, this refers to how competition between undertakings improves the goods and services that they offer on the market. Consumer welfare is enhanced when goods and services become better, cheaper, and more plentiful. The way in which undertakings compete, however, varies according to the market. Although undertakings will attempt to provide the overall 'best' offer, it is possible to differentiate between competitive parameters: typically price, choice, quality and innovation. The existence of different competitive parameters is a well-established notion in competition law. For example, in Post Danmark $I$, the Court stated that:

'Competition on the merits may, by definition, lead to the departure from the market or the marginalisation of competitors that are less efficient and so less attractive to consumers from the point of view of, among other things, price, choice, quality or innovation'.70

Similarly, the Commission has justified its focus on consumer welfare as an enforcement priority by stating that '[c]onsumers benefit from competition through lower prices, better quality and a wider choice of new or improved goods and services'. ${ }^{71}$ In addition to these recent endorsements, competitive parameters make scattered appearances in the (non-exhaustive) examples of restrictions of competition and abuses of dominance in the letter of Articles 101 and 102 TFEU.

Although the wording of Articles 101 and 102 TFEU does not provide a hierarchy of competitive parameters, the application of competition law has tended to focus on price. The reason for this rests largely on the mathematisation of the underlying economics of competition law, and partially because of the strong causal connection between price increases and consumer harm. However, one cannot escape what Ezrachi and Stucke call 'the significant, yet elusive nature of quality': on the one hand, it is widely acknowledged that quality is often more

\footnotetext{
69 Preliminary Opinion of the EDPS (n10) [33]. Ohlhausen and Okuliar also mention competition 'on consumer privacy protections' as an avenue for applying US antitrust, Ohlhausen and Okuliar, Competition, Consumer Protection, and the Right (Approach) to Privacy (n44) 17.

70 Post Danmark I (n28) 22.

${ }^{71}$ Enforcement Guidance on Article 102 TFEU (n34) 5.
} 
important than price; on the other, it is hard to define quality - let alone measure it. ${ }^{72}$ As these authors highlight, despite the difficulty in defining quality there are several decisions, in the EU and beyond, supporting the importance of quality as a competitive parameter. Therefore, from a theoretical (and occasionally practical) point of view, competition assessments based on a decrease of quality are just as legitimate as their equivalents based on an increase in price..$^{73}$

This may very well happen when, as discussed above, there is competition between undertakings for the acquisition of personal data. In markets where such data is disclosed in exchange for access to services which are free-at-the-point-ofaccess (or for a token fee), there are indications that some consumers are influenced by the undertaking's data use policy. ${ }^{74}$ Thus, the quality of the data use policy of each undertaking can become a competitive parameter relevant to the acquisition of personal data. In other words, as undertakings do not pay a monetary fee for this data, they are competing on the quality of the service offered as a counterpart, including the quality of their data use policy. Yet, as in other markets for goods and services, it is difficult to define quality in this regard: what makes one data use policy better than another? The variables are numerous: the amount of personal data, its nature and sensitivity, the possible uses of the data, whether it can be processed by third parties, the third parties uses, etc. As the Commission noted in its Intel decision, there may be no single factor defining quality. .75

We shall therefore consider how data protection may serve as a normative yardstick for assessing the quality of a data use policy, as competition law otherwise lacks the normative tools for this assessment. By way of comparison, when competition law is faced with price-fixing cartels or exploitative prices it has the normative tools - from its economic rationale - to judge the price increase to be anti-competitive. When it comes to the conditions offered for personal data, competition law can start from a similar premise that quality losses are bad but it cannot determine what exactly constitutes such quality. It must be emphasised that this assessment - of the quality of a data use policy - is not conducted by reference to what consumers want (an issue considered when defining the relevant market). Even when consumers are charged collusive or exploitative prices, they

\footnotetext{
72 Ariel Ezrachi and Maurice E. Stucke, 'The Curious Case of Competition and Quality' [2015] Journal of Antitrust Enforcement, 2015, 1. These authors indicate some of the heuristics used to overcome that difficulty, namely the assumption that competition increases quality for a given price (like it reduces prices for a given level of quality) or the price-quality correlation which consumers usually make. Ibid, 2.

${ }^{73}$ What the Court presently refers to 'competition on the merits' was even named 'competition on the basis of quality' in France Télécom. Case C-202/07, France Telecom SAv Commission [2009] ECR I-2369, [106].

${ }^{74}$ Preliminary Opinion of the EDPS (n10) [33]. See also the references to users switching away from WhatsApp after news of its acquisition by Facebook, as discussed below. Facebook/Whatsapp (n8) fn. [79] and [174]

${ }^{75}$ Case COMP/37.990, Intel, Commission decision of 13May 2009 [1691].
} 
pay for a good or service they want and pay what they believe it is worth to them..$^{76}$ It is competition law which intervenes normatively to find those prices to be anti-competitive. ${ }^{77}$ In contrast, competition law cannot judge when there is an equally anti-competitive loss of quality in data use conditions. It could, however, borrow this normative judgment from the data protection regime. At its essence, data protection establishes a framework for judging the treatment of personal data, with some practices deemed desirable and others not. Competition law could therefore make quality assessments in tandem with data protection. ${ }^{78}$

The following sub-sections will consider how this might work in practice, as well as possible objections to the use of data protection in this way, in relation to restrictions of competition under Article 101 TFEU (3.1.), abuses of dominance under Article 102 TFEU (3.2.), and merger control under the EUMR (3.3.).

\subsection{RESTRICTIONS OF COMPETITION}

Restrictions by object under Article 101 TFEU are characterised by their very nature, as being harmful to the proper functioning of normal competition', with the Court further acknowledging that horizontal collusion normally leads to negative effects on quality. ${ }^{79}$ An infringement of data protection law, in particular one which leads to lower quality processing of personal data, might therefore constitute a restriction of competition by object. If there is competition on data use conditions, industry collusion to set those conditions at a level which leads to an infringement of data protection law would effectively put a stop to that competition. ${ }^{80}$ The same reasons that make (other) cartels harmful to competition would apply here; in particular, there will be a loss of consumer welfare insofar as data protection law aims to protect data subjects. In this regard, it would not matter if all the consumers affected actually care about data protection, in the same way that they do not have to care about cartels: if there is competition on data conditions, such collusion is considered normatively censurable.

Establishing a restriction by object based on a data protection infringement would provide a simple and normatively well-grounded bright line which

\footnotetext{
76 That is demonstrated in the demand curve modelled by economists for any market.

${ }_{77}$ For various economic reasons that converge on the harmfulness of monopolies, from the inefficiency of reduced output and rent seeking to the transfer of surplus away from the consumer.

78 Although this section focuses on quality, a similar discussion could also apply to the competitive parameters of choice and innovation. The data protection regime may indicate that a wider breadth of competing data protection policies is preferable (regardless of differing quality and price), or encourage new improvements and functionalities of data protection that may themselves result in cheaper prices, more choice or better quality.

${ }^{79} \mathrm{CB}$ (n24) [51].

80 This could also extend to limiting competitive parameters along a single vertical relationship - what is called, in relation to price, 'resale price maintenance'.
} 
competition law would otherwise, on its own, be unable to draw. It would also place restrictions by effect below that line, as losses of quality which do not involve such an infringement. This does not however mean that the data protection regime would be irrelevant when assessing whether there is a restriction by effect. While data protection law allows data processing to be categorised as permissible or impermissible, it also provides broader normative indications about the desirable treatment of personal data. For example, incomplete information or weak consent may be enough to constitute a decrease in quality without constituting an infringement of the data protection regime. Establishing a restriction of competition in this way would be a more difficult exercise; however, restrictions by effect are in any event more difficult to prove in practice than restrictions by object. ${ }^{81}$ This being said, this sub-section will focus on restrictions by object, since basing them on data protection would already be an innovative development and, in turn, open the way for a more refined analysis of effects.

The best way to test the merits of this idea is to consider the objections it might raise. The most immediate objection is novelty: it could be argued that Article 101 TFEU has never been dependent on another field of law. This, the argument would go, would imperil the independence of competition law as a field of law with its own normative judgments. More practically, it could be argued that one difficult assessment - the quality of a data use policy - would simply be replaced by another- whether there has been an infringement of data protection law. Nevertheless, similar considerations did not deter the Court from relying on another field of law to find a restriction by object in Allianz. Hungária.82 In that judgment, the Court assessed whether agreements between insurance companies and dealers constituted a restriction by object by relying wholly on the independence of dealers mandated by domestic law. ${ }^{83}$ This law was an essential indicator of the 'proper functioning of normal competition': Article 101 TFEU was otherwise not normatively equipped to assess the quality of dealer services to which consumers were entitled.

A further line of objection could point to the precedent established by the Court in Asnef-Equifax when it stated that issues of personal data are not 'a matter for competition law' but for the data protection regime. ${ }^{84}$ It is nonetheless suggested that Asnef-Equifax may be limited to its facts. First, there was ostensibly no data protection infringement: if the hypothesis is that such an infringement could be internalised by Article 101 TFEU, it can only be tested if there is an infringement. In Asnef-Equifax, the Court seemed content to confirm that national data protection legislation was being respected. ${ }^{85}$ More importantly, there is no

\footnotetext{
${ }^{81}$ Mastercard (n26) [93] A restriction of competition by effect was described in Mastercard as an 'adverse impact on the parameters of competition, such as [...] quality of the goods or services'.

82 C-32/11, Allianz. Hungária Bižtositó and Others ECLI:EU:C:2013:160.

83 Allianz Hungária (n80) [47].

84 Asnef-Equifax (n7) [63]

85 ibid.
} 
indication in the judgment that the banks were competing for customers based on the quality of their data use policies. In the relationship between competition on the service provided - lending - and competition on data protection conditions, the former appears to subsume the latter. This impression could prove erroneous: if equipped with knowledge or awareness, borrowers might object to the sharing of their personal data between banks. Nevertheless, this line of inquiry was not pursued by the Court, potentially because its inquiry was limited by the facts raised before it. The Court therefore found that there was no restriction by object as there seemed to be no competitive concern, and such concern is a prerequisite for internalising a data protection infringement. ${ }^{86}$ It could be countered that competition on data use policies did exist, but any concern about the quality of such policies was trumped by the interest in securing the provision of credit against potential defaulting borrowers - thereby showing data protection's competitive irrelevance. However, these two interests were not squared against each other either. Thus, in the absence of an infringement affecting competition on data use policies, the question of the competitive relevance of data protection remains unresolved by Asnef-Equifax.

The final objection would be that internalising data protection would drag competition law away from its core normative concerns. In other words, Article 101 TFEU would be applied to safeguard the quality of data protection regardless of an overall detrimental effect on other competitive parameters or on the efficient functioning of the market. These concerns must however be placed in context, as a data protection infringement would only matter if there would be competition on data processing conditions - an opportunity which, as just noted, Asnef-Equifax failed to explore. If a restriction of competition on quality is present, it is doubtful that it is efficient or that a trade-off with other competitive parameters is allowed. ${ }^{87}$ As Ezrachi and Stucke note, and is evident in relation to cartels, 'competitors generally cannot justify their agreement to curtail competition along one important dimension (namely quality), on the grounds that they still compete along other dimensions (such as price)' 88

\subsection{AbUSE OF DOMINANCE}

If the main contribution of data protection to competition law is acting as normative yardstick for the assessment of quality, then this is reflected in

\footnotetext{
86 The sharing of information can also be said to address an externality - the effects of defaults on the availability of credit - rather than restrictions on the competitive process, leading to the same apparent lack of competitive concern. See further, Pablo Ibanez-Colomo, 'Market failures, transaction costs and article 101(1) TFEU case law' (2012) 37 European Law Review 541.

87 The opposite is true of restrictions by effect, which do balance different anti-competitive effects. This would assuage the mentioned concerns without denying the competitive value of data protection.

88 Ezrachi and Stucke, The Curious Case of Competition and Quality' (n72) 9.
} 
exploitative abuses under Article 102 TFEU. When undertakings are insulated from competitive pressure they are able to use their dominant position to exploit consumers, in particular by charging excessive prices. As excessive prices may be measured by comparison with prices deemed desirable, so too, it is suggested, can abusive data use policies be compared with those deemed desirable in light of data protection rules. Data protection would therefore again act as the normative yardstick in assessing the quality of a data use policy. There are even advantages to pursuing exploitation based on quality instead of price. First, it would enable exploitation by 'free' services offered online to be brought within the scope of Article 102 TFEU, as providers of such services cannot be accused of excessive pricing. Secondly, it would - to a certain extent ${ }^{89}$ - avoid the difficulty of having to offset reasonable profits (compensating for a dominant undertaking's investment and risk) when determining if prices are excessive, which in turn has made this abuse difficult to investigate and enforce. Lastly, the argument that prices above the competitive level are a reward for a good or service which consumers value would also not apply - there is no such justification for a low quality data use policy.

Finding an exploitative abuse under Article 102 TFEU based on the data protection regime would operate in a similar way to the finding of a restriction of competition under Article 101 TFEU, as outlined above. First, a data protection infringement would set a clear normative marker of inferior quality. If a dominant undertaking exploitatively reduces the quality of its data use policy, consumers will be worse off than had competitive levels prevailed - which, when there is competition on data use policy, must normatively be set at compliance with data protection law. Moreover, like restrictions by effect, even when there has not been a data protection infringement a negative effect on quality may be visible. For instance, in the same way that a sudden and unjustified increase in price has been found to be exploitative, a sudden decrease in the quality of the conditions for data processing might equally be exploitative. ${ }^{90}$ The extent to which a dominant undertaking is allowed to monetise personal data might also be considered exploitative if non-commensurate with the service granted to the consumer. ${ }^{91}$ There is an added advantage to applying Article 102 TFEU in comparison to Article 101 TFEU: while restrictions by object involve wide normative concerns over the 'proper functioning of normal competition' that might only affect

\footnotetext{
${ }^{89}$ As discussed next, this difficulty would be avoided if a data protection infringement would be present, but not in non-infringing exploitative monetisation.

${ }^{90}$ Case C-247/86, Alsatel v Novasam [1988] ECR I- 5987.

${ }^{91}$ See, Data Protection Commissioner, 'Facebook Ireland - Report of Audit', 21 December 2011, 44. This report states that the Commissioner'... does not consider that it is possible using data protection requirements as a basis to require FB-I to deliver a free service from which members can have the right to opt-out completely from the means of funding it. However, there is an absolute necessity that members be fully aware of what information generated in their use of the service will be used for advertising purposes thereby allowing them to exercise choice.'
} 
consumer welfare indirectly, and in this way counter data protection concerns with other valid competitive interests, exploitative abuses focus directly on consumer welfare.

Furthermore, precedent exists for using other areas of law as normative guidance on exploitative abuses, making this a promising area for the proposed role of data protection law. Intellectual property (IP) law is a case in point. The legal monopoly granted by IP law is assumed to be the reward for innovation, and as a result there is a general reluctance to deem prices charged for IP to be exploitative. ${ }^{92}$ It is often emphasised that applying competition law to IP might chill incentives to innovate. Nevertheless, one finds that a great number of excessive pricing cases have concerned IP. This paradox may be explained by the fact that IP law also provides normative indications of when a reward of monopolistic prices is adequate and when it is not. For instance, prices charged for licenses after the protection granted by IP law has expired have been considered exploitative..$^{93}$ Similarly, in DSD the Court found an exploitative abuse when licence fees were charged but the services protected by the trademark were not used. ${ }^{94}$ Although not pure infringements of IP law (such as when third parties make unauthorised uses of IP), the reasoning underpinning these cases is clear: competition law is not normatively equipped to determine when the price charged for IP is excessive in relation to its duration and scope. ${ }^{95}$

Perhaps the biggest challenge of allowing data protection to influence exploitative abuses is the impact that this would have on other areas of law, most notably facets of consumer protection law. Behind the conceptual clarity of equating a data protection infringement with the abusive exploitation of consumers lie significant practical consequences. The danger is that it would be as easy to find that an abuse of dominance by reference to multiple other areas of law. It could thus be argued that any rule with the aim to protect consumers could potentially be applied as an exploitative abuse. This could upset the balance of how much consumer protection is warranted and distort the purpose of Article 102 TFEU.

\footnotetext{
${ }_{92}$ The costs of producing IP usually do not reflect its value, and even if the profit seems excessive it does take into account the failed attempts and the incentive to achieve it. A legal monopoly might not correspond to a competitive one.

93 Spreading the licences over a period larger than the intellectual property protection might be a legitimate pricing strategy, hence the abuse is not automatic, but further protection will usually indicate that the holder is attempting to leverage its current revenues into a non-protected period.

${ }^{94}$ Roughly speaking, trademarks guarantee the reputation of the holder, which is not at stake when its services are not used. T-151/01, Duales System Deutschland v Commission [2007] ECR II-01607.

95 Prices for design rights for spare parts have also been considered open to exploitative abuses: Case C238/87 AB Volvo Veng v Erik Veng (UK) Ltd [1988] ECR 6211. This can be attributed to a hold-up problem, but the fact that competition law has intervened (which it does not necessary do in all hold-up problems) is likely due to the consideration of the purpose of design rights.
} 
It must however be considered that consumer protection is not a unified field of law, but an assemblage of laws with each aiming to protect different consumer interests and triggered by differing facts. In this assemblage, it is the role of Article 102 TFEU to ensure that undertakings do not abuse their dominant position by raising prices, lowering quality or otherwise harming consumer welfare. This means that exploitative abuses are triggered by actions which negatively affect competitive parameters which should benefit consumers. As such, it is false to assert that any infringement of rule of consumer protection by a dominant undertaking would automatically lead to an exploitative abuse - Article 102 TFEU would only be called into action by its particular trigger, which may or may not be present in any given scenario. The concurrent application of several fields of consumer protection law cannot be dismissed easily, and neither can their mutual normative influence. Therefore, whether dominant undertakings can be pursued for breaches of other fields of consumer protection depends on whether Article 102 TFEU's own terms are fulfilled.

Similar reasoning applies when considering whether exclusionary abuses are open to the normative influence of data protection law. As discussed above, data can constitute a market barrier when it is an input required for the production of other goods and services. These market barriers may be manipulated as part of an exclusionary strategy. To a large extent, such exclusionary strategies can be analysed by treating personal data like any other market barrier. This, as will be discussed, is what happens when the creation or strengthening of a dominant position is examined in merger control. Outside merger control, competition law does not generally prohibit barriers to entry leading to market power - these barriers might simply reflect positive aspects of undertakings' performance which competitors have trouble emulating. Whether the acquisition of personal data allowing such barriers to be erected can be equated with any other form of consumer goodwill or with an exclusionary strategy is the key question. Data protection law might be influential in answering it, by providing a normative judgment on the creation of a market barrier based on personal data. This issue will be explored by considering the test for abuse of dominance in the context of misleading applications for IP protection.

In AstraZeneca' 96 the Court stated that it was an abuse 'to lead the public authorities [to] wrongly to create regulatory obstacles to competition, for example by the unlawful grant of exclusive rights to the dominant undertaking. ${ }^{97}$ If a market barrier was created by personal data, similar objections could be raised if that data was acquired on the basis of deceit - for instance, if an undertaking deviated from its stated data use policy in a significant manner. It could be argued that, contrary to AstraZeneca, the deceit would not in this case be directed to public authorities. This was nevertheless a specificity of the IP at issue in AstraZeneca, as many other forms of protection do not require public authority intervention.

\footnotetext{
${ }^{96}$ Case C-457/10, AstraZeneca v Commisson ECLI:EU:C:2012:770.

97 ibid, [105].
} 
Extending the AstraZeneca logic to market barriers created by personal data will depend on whether the legal character of the barrier matters (regulatory, public authorities) more than its economic significance (deceit, foreclosing competitors). What makes the analogy feasible is that the Court reached out to IP law - in relation to what constituted a properly attributed exclusive right - to establish that the resulting barrier was outside 'competition on the merits'. ${ }^{98}$ It is conceivable that a similar determination could be made in relation to personal data based on the data protection regime.

The most relevant objection to such an abuse (besides its speculative character) relates again to the extension of the scope of Article 102 TFEU. If deceit were a viable basis for abuse, then it could be argued that other fields of consumer protection that are information-forcing - advertising, labelling, etc. could lead to the same result. It must be remembered however that the basis of the abuse is the market barrier, starting from an analogy with the exclusive right granted by IP law. The information covered by these other fields is unlikely to constitute a market barrier. Nevertheless, if such a barrier could be equally established in solid economic terms, there would be nothing to prevent the analogy from also being pursued. In the same way that a dominant undertaking has no right to make deceitful declarations for the purpose of creating an IP market barrier, neither would it have a right to deceive in its advertising or labelling to similar effect.

\subsection{MERGER CONTROL}

Under the EUMR, a concentration might be prohibited (or conditions imposed upon it) if it leads to the creation or strengthening of a dominant position. The Commission has connected this dominant position with likely effects on consumer welfare, namely on the competitive parameters of price, quality, choice and innovation. These effects are analysed by investigating whether the concentration leads to the removal of competitive constraints. ${ }^{99}$ Although quality is thus only indirectly relevant, merger control remains an important testing ground for the normative influence of data protection on competition law. First, in contrast with the relatively untested nature of quality-based cartels or exploitation, negative effects on quality are expressly taken into consideration by merger control. Secondly, whereas it is possible to argue that competition on data use policy might be overlooked in cases such Asnef-Equifax, a preliminary reference concerned with the particular questions put before the Court, the

\footnotetext{
98 It is also possible that such deceit could be considered an 'exceptional circumstances' leading to a refusal to licence IP being considered abusive or integrated in circumstances similar to a so-called 'patent ambush'. Case C-418/01 IMS Health [2004] ECR I-5039.

${ }_{99}$ Horizontal Merger Guidelines (n33) [8] and [24]-[38]. In addition, this removal might lead to greater transparency and parallel behaviour in the market via coordinated effects.
} 
markets involved in any concentration notified to the Commission must be examined in full.

If there is such a thing as quality-based competition on data use policy, it is therefore legitimate to ask why it has not yet been recognised in merger control. The Commission's approach in Google/Doubleclick of applying data protection and competition law concurrently was described above. In Facebook/WhatsApp, the Commission reaffirmed that:

'[a]ny privacy-related concerns flowing from the increased concentration of data within the control of Facebook as a result of the Transaction do not fall within the scope of the EU competition law rules but within the scope of the EU data protection rules'. ${ }^{100}$

This ostensibly unequivocal statement must however be considered in the context of the decision as a whole. The Commission did not consider personal data as an independent product because the parties to the merger were not deemed to be active in markets for the supply or treatment of such data as a commodity. ${ }^{101}$ The Commission only considered the ancillary use of personal data in the market for online advertising services. ${ }^{102}$ As such, the above statement must be understood as part of the debate on external constraints addressed below: the Commission is declining to use its competence under the EUMR to address non-competitive concerns. Nevertheless, there are indications that there is competition on the basis of the quality of data use policy throughout the Facebook/WhatsApp Decision. In relation to the market for consumer communications services, the Commission notes that:

'consumer communications apps compete for customers by attempting to offer the best communication experience. [...] In this regard, according to the market investigation, important areas of improvement include: [...] (ii) privacy and security, the importance of which varies from user to user but which are becoming increasingly valued, as shown by the introduction of consumer communications apps specifically addressing privacy and security issues'. ${ }^{103}$

Thus, the Commission observes that after the announcement of the concentration many users changed services due to privacy concerns. ${ }^{104}$ Furthermore, in relation to the market for online advertising services, the Commission notes that the possibility of Facebook extending online advertising to WhatsApp would be

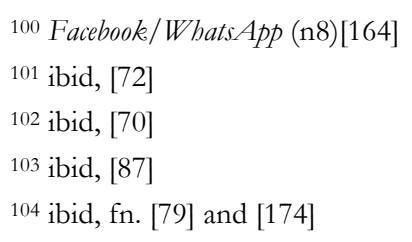


seriously limited by 'dissatisfaction among the increasing number of users who significantly value privacy and security'. ${ }^{105}$ Thus, the Commission recognises that competition exists on the basis of data use policies.

This then begs the question: why did the Commission not consider whether the merger would lead to a reduction of such competition? It did not do so in this instance as the parties were not considered to be close competitors on the market for consumer communication services. As such, it was not necessary to consider whether the merger would lead to a reduction in the quality of data use policies. In other words, competition for data protection quality existed but the parties to the merger were not engaging in it. 106 The furthest the Commission goes is to consider (and dismiss) the competitive harm that would follow should online advertising be introduced to WhatsApp, or should Facebook be able to improve its advertising services based on WhatsApp data. ${ }^{107}$ Again, the Commission was only concerned with the strengthening of the dominant position on the market for online advertising - that is to say, by Facebook pulling ahead of its rivals - rather than the quality of the data use policy. ${ }^{108}$ The implications of this reasoning are clear: the Commission believes that there is competition on quality aspects of data use policies, and that consumer preferences limit the post-merger actions of the merged entity. However, the market power resulting from Facebook/Whats App did not raise particular competitive concerns as the Commission found no overlapping competitive activity.

One could conclude that data protection provides no normative influence in this regard: the Commission acts no differently in Facebook/WhatsApp than in numerous other concentrations. Once the Commission relegates (in its view, noncompetitive) data protection concerns to the separate application of data protection law, it then appears to assess the negative effects on the quality of data protection through purely economic methods of gauging consumer preferences. However, an alternative reading of this Decision is suggested. Facebook/Whats App examines negative effects for consumers along the normative lines drawn in the data protection regime, namely the concerns about data protection and privacy which, by the Commission's own admission, influence competition. Without data protection, it would be harder for competition law to ascertain whether those effects are truly negative: for example, it could be considered that consumers would always benefit from more targeted advertising. Indeed, outside the legal framework of data protection the notions of 'privacy' and 'data protection' would prove normatively empty for the purposes competition law. The fact nevertheless remains that the Commission does not consider those effects directly, but only

\footnotetext{
105 ibid, fn. [174]

106 Indeed, one of the reasons why the Commission determined that they were not competing was because of their different privacy policies, ibid, fn. [102]

$107 \mathrm{ibid}$, fn. [167]

108 ibid, [187]
} 
indirectly through the analysis of market power. In the end, Facebook/Whats App appears inconclusive: without concerns about market power, the Commission did not have to investigate negative effects in more detail and provide further guidance on the loss of quality of data protection. This ends up being quite similar to the lack of competitive concerns which was seen above to have prevented further inquiry into a restriction by object in Asnef-Equifax.

If ever a merger involving competition on data use policy raises concerns about a dominant position then the normative influence of the data protection regime will undoubtedly be easier to ascertain. Yet, it is suggested that Facebook/Whats App also provided the Commission with the opportunity to take data protection concerns into account from another perspective. It must be remembered that the creation or strengthening of a dominant undertaking is only a 'particular' concern covered by the Merger Regulation. ${ }^{109}$ In Tetra Laval the Court found that, in examining a merger, the Commission was justified in considering past abusive behaviour by one of the parties to the merger and requiring corresponding commitments. ${ }^{110}$ As the Court stated explicitly, it is not the sole role of the Commission under the EUMR to prevent the creation and strengthening of a dominant position; the Commission must also consider the incentives for the abuse of such position post-merger. ${ }^{111}$ This would also apply if, as discussed above, data protection could influence the finding of an exploitative abuse. As such, even if there are reasons to dismiss concerns about a dominant position in Facebook/WhatsApp, the Commission could have been obliged to explore whether one of the parties would further exploit its consumers. An infringement of the data protection regime could therefore affect merger control beyond the assessment of the dominant position of the merged entity. This is another reason why a merger leading to a data protection infringement could make the Commission reconsider its position on concurrent application.

\section{DATA PROTECTION AS AN EXTERNAL CONSTRAINT ON COMPETITION LAW}

When examining the ways in which data protection law could be incorporated in the existing analytical framework of competition law, and thereby exert an internal constraint, the fundamental right character of data protection has not been taken into consideration. This section will consider whether, beyond the pre-existing confines of competition analysis, data protection can influence the interpretation and enforcement of competition law. As already stated, the Charter introduces a

\footnotetext{
109 Merger Regulation (n30) Art. 2(3).

110 C-12/03 Commission v Tetra Laval BV [2005] ECR I-987. This involved discrimination, which is not an issue where normative influence of data protection is likely to play out.

111 ibid, [159].
} 
right to privacy and data protection in the EU legal order. The Charter is addressed to the 'institutions and bodies of the Union' and also to the Member States when 'implementing EU law'.112 Moreover, although the horizontal effect of the Charter has been disputed (as the Charter is only explicitly addressed to the EU Institutions and Member States), the Court affirmed in $A M S^{113}$ that the fundamental rights guaranteed by EU law are 'applicable in all the situations governed by EU law'. ${ }^{114}$ In that case the relevant Charter right was not given horizontal effect as the Court held that in order for it to be fully effective it had to be given 'more specific expression in European Union or national law'.115 The right to data protection has already been given such specific expression in EU secondary legislation, through the Directive, and in national law through implementing legislation. There is therefore no obstacle to the application of the right to data protection between private parties. Indeed, this follows from the Court's reasoning in the case of Google Spain where it assessed Google's responsibilities as a data controller in light of the rights to data protection and privacy, thereby ensuring the horizontal application of these rights. ${ }^{116}$

The Charter rights to privacy and data protection are thus binding on the Commission when exercising any of its competences, and on private parties when acting within the scope of EU law. When considering this, it is necessary to bear in mind the distinction between positive and negative obligations pursuant to fundamental rights law. The European Court of Human Rights (ECtHR) has repeatedly held that the right to respect for private life may involve the adoption of measures designed to ensure respect for private life even in the sphere of the relations of individuals themselves'. ${ }^{117}$ Such positive obligations ensure that certain fundamental rights provide protection by the State in addition to the widely recognised protection from the State. ${ }^{118}$ Thus, it is suggested that the external constraints of data protection on competition law could be formulated as negative and positive obligations. First, data protection could impose a negative obligation to limit certain private arrangements from falling within the scope of competition law, in order to respect the parties' rights to privacy and data protection (4.1.). Secondly, data protection could place a positive obligation on the Commission to promote the effective application of the right to data protection (4.2.).

\footnotetext{
112 Art 51(1) EU Charter.

${ }_{113}$ Case C-176/12 Association de médiation sociale v Union locale des syndicats CGT and ors ECLI:EU:C:2014:2.

114 ibid, [42].

115 ibid, [45].

116 Google Spain (n13).

117 See, for instance, X \& Y v Netherlands (1985) 8 EHRR 235, [23].

118 See further, Andrew Clapham, 'The "Drittwirkung” of the Convention' in R St J McDonald, F Matscher, and H Petzold (eds), The European System for the Protection of Human Rights (Martinus Nijhoff Publishers, 1993) 163, 190.
} 


\subsection{RESTRICTION OF THE SCOPE OF COMPETITION LAW}

The primary way in which competition law can be constrained by an external norm is by preventing its application and thereby reducing its scope. Competition law is sometimes constrained in this way by its interaction with other areas of EU law, either explicitly in the Treaties or because of an implicit incompatibility of goals. An example of explicit exclusion is Article 106(2) TFEU, which provides that undertakings entrusted with public service obligations (or 'services of general economic interest') will only be subject to competition law to the extent that this does not obstruct the performance of their particular task. Albany is an example of an implicit exclusion, with the Court considering that social policy objectives would be undermined if collective labour agreements were subject to Article 101(1) TFEU.119 It is suggested that data protection's status as a fundamental right would give it the required legal precedence to operate in the latter fashion, and exclude the application of competition law altogether if necessary. Nevertheless, the commonality of goals between data protection and competition law, as well as the concurrent application suggested by the Court in Asnef-Equifax, does not point to a solution such as that in Albany. Rather, it is suggested that data protection law could prevent the application of Articles 101 and 102 TFEU (subject to a proportionality judgment), in a similar vein to Article 106(2) TFEU and to the Wouters ${ }^{120}$ case law discussed below. ${ }^{121}$

Data protection law could thus operate like a justification for restrictions of competition or abuses of dominance. ${ }^{122}$ In Wouters the Court held that a ban of the association between lawyers and accountants stemming from self-regulation of the legal profession restricted competition, but ultimately did not breach Article 101 TFEU since it ensured that 'the ultimate consumers of legal services and the sound administration of justice are provided with the necessary guarantees in relation to integrity and experience'. ${ }^{123}$ This jurisprudence was subsequently extended to restrictions necessary to enforce doping bans in Meca-Medina, where the Court expressly stated that such restrictions had to be proportionate to the objectives pursued. ${ }^{124}$ While the interpretation of Wouters remains controversial,

\footnotetext{
119 Case C-67/96 Albany [1999] ECR I-5751, [59].

120 Case C-309/99 Wouters and Others [2002] ECR I-1577.

121 The distinction between justification and a restrictive interpretation of the conditions of Article 101 TFEU is admittedly fine, as shown by FENIN (Case C-205/03, FENIN v Commission [2006] ECR I-6295, [27]) in relation to the notion of undertaking and the German books case in relation to the effect on trade between Member States criterion (German books Press Release IP/02/461, 22 March 2002). Wouters itself, by stating that not all restrictions of freedom of action fall within the scope of Article 101(1) TFEU and referencing the context usually considered by restrictions of competition, could also be read in this latter way. Wouters (n120) [97].

122 Objective justifications for an abuse of dominance have been admitted by the Court but none has yet been they applied, so the present discussion will concentrate on the Wouters case law.

123 Wouters (n120) [97].

124 Case C-519/04P David Meca Medina and Igor Majcen v. Commission (2006) ECR I-6991, [45].
} 
the proportionality test made explicit in Meca-Medina points towards the introduction of a rule of reason in competition law similar to the one applied in internal market law. ${ }^{125}$ Since the seminal Cassis de Dijon judgment, Member States may invoke overriding public policy objectives, ranging from the protection of the environment to public health, in order to justify what would otherwise constitute an interference with the Treaty free movement provisions. The scene had already been set for such a development in competition law in Deliege ${ }^{126}$, a case involving both internal market and competition law, when Advocate General Cosmas noted that 'rules which, at first sight, reduce competition, but are necessary precisely in order to enable market forces to function or secure some other legitimate aim, should not be regarded as infringing [competition law]. ${ }^{127}$ Moreover, in Pierre Fabre128 the Court made an explicit comparison between a 'legitimate aim' pursued by a restriction in competition law and an overriding public policy objective accepted in internal market law. ${ }^{129}$

Interpreting the Wouters case law in this way would facilitate the inclusion of data protection law amongst the public policy justifications for what would otherwise be a breach of competition law. The protection of fundamental rights has long been accepted as a justification in internal market jurisprudence. In Omega ${ }^{130}$ the Court considered that a ban on a laser game simulating human killing breached the freedom to provide services, but accepted that such a ban was justified as it violated the right to human dignity. In so doing, the Court noted that human dignity is a general principle of law which the EU legal order 'undeniably strives to ensure respect for'. 131 The recognition that the protection of fundamental rights may constitute a valid justification for a breach of internal market law is a further indication that EU law's regulation of economic activity is subject to fundamental rights constraints. It is therefore argued that a restriction of competition necessary to protect fundamental rights could not fall foul of Article 101 TFEU. Indeed, Monti suggests that, in Wouters, 'the Court was duty bound to deploy a solution that would ensure that the public policy of the Member State is given equal relevance regardless of the means by which the policy is implemented (i.e. by legislation or private party conduct)'.132 This reasoning applies more forcibly if the policy does not originate in a Member State but is an obligation imposed by the Charter.

\footnotetext{
125 Giorgio Monti, Article 81 EC and public policy (2002) 39 Common Market Law Review 1057.

${ }^{126}$ Joined Cases C-51/96 and C-191/97, Deliège [2000] ECR I-2549.

127 Monti, Article 81 and public policy (n125) 1088.

${ }^{128}$ Case C-439/09 Pierre Fabre Dermo-Cosmétique S A [2011] ECR I-9419.

129 ibid [43-44]

${ }_{130}$ Case C-36/02 Omega Spielhallen- und Automatenaufstellungs-GmbH v Oberbürgermeisterin der Bundesstadt Bonn [2004] ECR I-9609.

131 ibid, [34].

132 Monti, Article 81 and public policy (n125)1089
} 
Yet, it is suggested that the use of data protection in this way - to justify what would otherwise be anticompetitive conduct - may not be very widespread. This is because data protection legislation already applies horizontally between private parties. Since undertakings are compelled to respect the legislation implementing the Directive, undertakings could rely on the State compulsion doctrine in order to justify breaches of competition law required by data protection. ${ }^{133}$ Nevertheless, some actions by undertakings might seek to facilitate the effectiveness of data protection without their omission constituting an infringement. Those actions, in turn, might be considered anti-competitive and therefore require justification. This is not a hypothetical scenario. The preliminary opinion of the EDPS explores several measures that would favour the control of users over their personal data, such as 'standards for transparency and intelligibility of contractual terms in online services' and a 'right to data portability [allowing] users to transfer between online services'. ${ }^{134}$ Although the EDPS is confident that these measures would increase competition, any standardisation effort runs the risk of allowing undertakings to align their behaviour and stifle innovation. Thus, undertakings engaging in industry agreements with the purpose of standardising contractual terms or technical requirements in order to facilitate data portability may find themselves subject to an allegation of infringement of Article 101 TFEU. Assessing whether such an infringement is present would involve an examination of whether the choice afforded by portability outweighed the long-term effects of aligning data use conditions. As litigation over standardisation of other economic activities indicates, this assessment might not look favourably on industry efforts. In such circumstance, a justification based on the Wouters doctrine could provide a much needed, and simple, solution.

\subsection{Guaranteeing the Effectiveness of the Right to Data Protection}

As an EU institution to which the Charter rights to privacy and data protection are addressed, the Commission is under a positive obligation to promote the effectiveness of these fundamental rights. This positive obligation is respected, in part, if data protection is allowed to act as an internal constraint on competition law. By resorting to data protection as a normative yardstick, the Commission will undoubtedly be contributing to the effectiveness of the right to data protection. That obligation is further complied with if competition law applies independently of the normative influence of data protection but still achieves results that further data protection concerns, such as preventing discrimination between users or the accumulation of market power that can be leveraged by undertakings in compelling users to disclose data. This shows the normative coherence of EU law, as areas with common goals reinforce each other.

\footnotetext{
133 Joined Cases C-359/95 and C-379/95, Commission of the European Communities and French Republic v Ladbroke Racing Ltd. (Ladbroke Racing) [1997] ECR I-6265, [33].

134 Preliminary Opinion of the EDPS (n10) [26] and [83].
} 
The obligation to guarantee the effectiveness of the right to data protection can nevertheless go further, and externally condition the enforcement of competition law. Such external conditioning would depart from competition law's internal logic and demand an added consideration of data protection concerns. In principle, this does not seem feasible given the Commission's stated policy of applying data protection and competition law separately. Thus, DG Competition (the directorate general of the Commission in charge of competition matters) has refused to investigate the consequences of applying data protection law to the competitive issues it handles. This policy nevertheless means that the DG Competition might be confronted with competitive actions by undertakings that imperil the right to data protection but refuse to take positive action. As just seen, there are strong indications that this separation does not apply to negative action: under the Wouters case law, DG Competition would have to accept data protection as a valid restriction of the scope of competition law. Thus, by refusing to take more proactive measures, the Commission as a whole may equally fall short of its obligation to ensure the effectiveness of fundamental rights protection.

Any such positive obligation would not however be unlimited: it could not require DG Competition to exercise its investigative and sanctioning powers due to an equally strong limitation by the principle of legality. If DG Competition pursued data protection infringements as competition law infringements simply because they involved an agreement or an undertaking in a dominant position (and not because it would be constrained to do so by the internal logic of Articles 101 and 102 TFEU), it would be usurping the competences it was attributed by EU law and inadmissibly expanding the remit of competition law. The status of data protection as a fundamental right is not liable to change this, since the use of competition law sanctions to guarantee the right to data protection would also breach the principle of legality as set out in Article 7 of the ECHR. ${ }^{135}$ Without a competition law 'hook', DG Competition cannot pursue undertakings. The complaint to DG Competition by 'Disconnect', the provider of a privacy and security enhancing application for smartphones and devices, may be a case in point. ${ }^{136}$ In that complaint, Disconnect suggests that it has been excluded from the Android Operating System's Google Play store. Unless it can be demonstrated that this exclusion is discriminatory or exclusionary under the logic of Article 102 TFEU (notably, that the Google Play store is an essential facility) it is unlikely that this complaint will be successful despite the potentially negative impact of Google's policy on the effectiveness of individual data protection and privacy rights. In the absence of regulation or the relevant criteria for an Article 102

\footnotetext{
135 A. Menarini Diagnostics srl v. Italy, App. No 43509/08, not yet reported, 27 September 2011.

136 Wall Street Journal, 'App Maker Files EU Complaint Against Google, Alleging Abuse of Android Dominance', 1 June 2015: http://www.wsj.com/articles/app-maker-files-eu-complaint-against-googlealleging-abuse-of-android-dominance-1433204706, accessed 2 November 2015.
} 
TFEU investigation, if DG Competition intervened in such an instance it would be acting beyond the scope of its powers.

This limitation nevertheless does not negate the Commission's obligation to ensure that, when acting in the field of competition law, its actions promote the effectiveness of data protection rules. This is evident in the obligation, stated at the outset, on the Commission to respect the right to data protection in its investigations of competition law. What is further suggested is that the Commission should guarantee the effectiveness of the right to data protection by ensuring that its competences are not (mis)used in a manner which hinders the effective application of data protection law. That would notably be the case if the Commission is asked to confer a benefit on an undertaking (or undertakings) in the context of a competition law assessment that would diminish the effectiveness of the right to data protection. In such circumstances, the Commission should withhold the benefit until it becomes apparent that, by conferring it, it would comply with the positive obligation to respect the right. This would not unduly expand the scope of competition law, as there would always be a competitive concern triggering it. The exercise of the Commission's competences would simply be subject to a positive obligation to guarantee the effectiveness of the right to data protection, in the same way it is already unquestionably subject to a negative obligation to refrain from infringing this right itself. Any failure to comply with these obligations would be reflected in the validity of a Commission decision.

In its Google Spain judgment, the Court placed significant emphasis on the need to ensure the effectiveness of EU data protection law when interpreting the provisions of the Directive. ${ }^{137}$ For instance, when stating that Google may be under an obligation to remove links from its index, the Court noted that the effective and complete protection of individuals could not be guaranteed if these individuals were obliged to have this information also erased from the initial host publisher. ${ }^{138}$ Thus, the effectiveness of the data protection regime requires private parties to do what they can within their sphere of action, regardless of other avenues of enforcement. If a private party can be obliged to act in this manner, it is arguable that an EU Institution would be under an equally strong, if not stronger, duty to promote the effectiveness of the rights addressed to it. This could curtail the Commission's usual discretion in exercising its competences to apply competition law. ${ }^{139}$

\footnotetext{
${ }^{137}$ Google Spain (n13) [30], [34], [38], [53], [58] and [84].

138 Google Spain (n13) [84].

${ }^{139}$ In its Schrems judgment, the Court recognised that the discretion of the Commission is limited when making an assessment under the Data Protection Directive regarding the adequacy of the protection offered by a third-country. The reason offered by the Court in that case was that the protection of personal data plays an important role in the protection of private life and that the Commission's adequacy assessment might have an impact on the fundamental rights of a large number of individuals. Case C362/14 Maximillian Schrems v Data Protection Commissioner ECLI:EU:C:2015:650.
} 
Merger control would provide the prime example of how such exercise may diminish the effectiveness of the right to data protection. When the Commission clears a merger, it is not putting an end to a sanctioning procedure: it is granting the parties to the concentration the authorisation to go ahead with an operation which would otherwise lack effect. ${ }^{140}$ As discussed above, the Commission may consider the impact that a concentration may have on the quality for data use policies if such competition exists. However, it is also suggested that the right to data protection can lead to a further parallel assessment of the impact of the merger on data protection regardless of data use policies being a competitive parameter. Thus, the Commission could be required to withhold its decision on a concentration until satisfied that merger clearance would not breach, or detract from the effectiveness, of the right to data protection. ${ }^{141}$ This would be especially relevant in the context of mergers given the particular privacy and data protection concerns which the amalgamation of data sets entail. As also noted by the EDPS, personal data reveals more than the sum of its parts. ${ }^{142}$ Therefore, in a merger context, by allowing two companies to combine previously separate data sets, the information gained about the individual may be far more revealing than if these data sets are separately maintained. ${ }^{143}$ This is often why such mergers have an 'added value' from a commercial perspective: they may provide a (disproportionate) insight into the life and interests of the individual.

A positive obligation would also apply where the Commission imposes conditions to clear a merger or accepts commitments from an undertaking to end an investigation under Articles 101 and 102 TFEU. On the one hand, the Commission would not be able to suggest a merger condition or accept a commitment that would require the undertakings to violate, or undermine, data protection law. This may seem evident, yet the sharing of personal data is often suggested as a remedy to claims of market power when only one entity has control over a large personal data set. ${ }^{144}$ However, it must be borne in mind that if

\footnotetext{
140 Merger Regulation (n30) Art 7(1).

141 A similar situation could be envisaged in relation to an exemption under Article 101(3) TFEU insofar as it also grants the benefit of validity to agreements that would otherwise be null and void due to Article 101(2) TFEU.

142 Preliminary Opinion of the EDPS (n10) [9].

143 The EDPS suggests that merger control should consider the impact on consumer welfare of the amalgamation of data in the event that the combined [personal data] were later processed for incompatible purposes', Preliminary Opinion of the EDPS (n10) [30]. However, undue processing should not be assumed to automatically follow from amalgamation or from any large aggregation of personal data, either as part competitive analysis (the reason why the Court considered previous discrimination by one of the merging parties as grounds for possible future abuse Tetra-Laval) or to guarantee the effectiveness of the right to data protection (since undertakings should not be presumed to infringe data protection simply because they have ample opportunity).

144 The EDPS even shows concern that data protection might serve as a 'shield' against such remedies, Preliminary Opinion of the EDPS (n10) [31].
} 
consent has been relied upon as a legal basis for the personal data processing, any such transfer would be subject to the renewal of this consent. ${ }^{145}$ Moreover, transfers of personal data between undertakings must respect the principle of purpose limitation. Pursuant to this principle, data collected for one purpose should not be processed for another incompatible purpose. For example, if personal data is collected by a social networking site it might not be possible to transfer them to the provider of a mobile phone application. Even if both are competitors from a competition law perspective, from the perspective of the individual the purposes of the data processing may - depending on a contextspecific assessment - be incompatible.

On the other hand, the extent to which the Commission can require an undertaking to take steps to address data protection concerns as part of the commitments offered by undertakings is debatable. ${ }^{146}$ Clearly, guaranteeing the effectiveness of the right to data protection is not part of the competition law infringement which the commitments are supposed to address. ${ }^{147}$ The Court has nonetheless accepted that commitments may go beyond this infringement and lead to structural reform of the market, prompting criticism that the Commission is expanding its powers for regulatory purposes. ${ }^{148}$ Introducing data protection concerns would exacerbate these objections. Nevertheless, the fact remains that, as in the context of merger clearance, the Commission materially confers a benefit when accepting commitments from undertakings and is under a positive obligation to guarantee the effectiveness of the right of data protection. Thus, the Commission should go further than refusing to accept remedies that infringe that right, and also require that commitments offered by undertakings do not detract from the right's effectiveness. This will not unduly extend the scope of competition law as long as remedies are limited to those otherwise admitted (no matter how flawed) as commitments.

It could be argued that the described emphasis on effectiveness, as well as the Court's finding that the Commission's discretion is limited when the right to data protection is at stake, applies only when the EU's data protection rules are at issue and thus should not impact on the activities of DG Competition. However, it is submitted here that there is a general obligation on the Commission to ensure, at minimum, that any of its decisions do not detract on the effectiveness of the right to data protection. This obligation follows from the collegiate nature of Commission decision-making and from the new structure of the Commission. First of all, the Commission is bound to 'act collectively' in accordance with the

\footnotetext{
145 This follows from the specificity criterion in the notion of consent. Directive 95/46 (n5) Art 7(a).

146 The EDPS considers several remedies 'which address the harm to individuals' privacy' that might fall under this category insofar as they are not directly related to a competitive harm, Preliminary Opinion of the EDPS (n10) [32].

147 Monti, Article 81 and public policy (n125)1076.

148 C-441/07, Commission v Alrosa [2010] ECR I-5949. See generally, Niamh Dunne, 'Commitment Decisions in EU Competition Law' (2014) 10(2) Journal of Competition Law \& Economics 399.
} 
Rules of Procedure of the Commission ${ }^{149}$, which state that 'Commission decisions shall be adopted if a majority of the number of Members specified in the Treaty vote in favour'. Therefore, for instance, while the decision to grant clearance to a merger may emanate from DG Competition, it must be approved by the Commission as a collective unit. Furthermore, since the entry into force of the Lisbon Treaty, the Commission President may appoint a Vice-President with responsibility for, inter alia, ensuring respect for the rule of law and the Charter. One practical consequence of this new horizontal cross-cutting role could be to ensure that fundamental rights, including the right to data protection, are taken into account in implementing policies and activities, and, crucially, in Commission decision-making. In this context, the Commission would simply be ensuring that one of its decisions - to clear a merger or accept commitments - would not breach the right to data protection, or jeopardise its effective application. Indeed, it could be argued that this is not a choice for the Commission, rather it is an obligation stemming from the Charter.

The objections to such a role for the Commission are predictable. The most obvious argument is in the line of Easterbrook's observation that 'when everything is relevant, nothing is dispositive..150 It might be argued that introducing data protection concerns in the application of competition law is a slippery slope: why not then incorporate other fundamental rights such as those binding anti-discrimination, labour relations, and so on. It is suggested in response that if such Commission intervention is justified in the data protection context, it should not be withheld simply because this would also force the Commission to protect other rights. On the contrary, the common characteristics of data protection and competition law might make this intervention more appropriate than regarding other rights. The fact remains however that either the Commission is bound by fundamental rights, or it is not: the wording of the Charter explicitly affirms that it is.

A second objection might be that the assessment of the impact on the right to data protection would be beyond the sphere of expertise of DG Competition. The Commission has objected to the inclusion of non-competition assessments within its remit for over a decade. For instance, in a White Paper dating from 1999, it stated that the purpose of Article 101(3) TFEU is to 'provide a legal framework for the economic assessment of restrictive practices and not to allow the application of competition rules to be set aside because of political considerations'. ${ }^{151}$ This problem can be avoided by recognising that this assessment would be an external non-competition assessment, not an internal interference with the logic of competition law. Article 21 of the EUMR already

\footnotetext{
149 Rules of Procedure of the Commission [2000] OJ L308/26).

150 Frank H. Easterbrook, 'Limits of Antitrust' (1984) 63 Texas Law Review 1, 12.

151 Commission, White paper on modernization of the rules implementing Articles 85 and 86 [1999] OJ C132/1, [57].
} 
allows for such non-competition assessments by Member States in certain circumstances, for instance in order to safeguard media plurality. It is thus suggested that the Commission would be required to uphold the right to data protection through a similar non-competition assessment. One might question why this would fall to the Commission rather than the Member State: the answer is clear, the Commission has the competence to act in the data protection context, visible through data protection legislation (while it does not have this competence to safeguard the right to freedom of expression). One might also question how this power of the Commission might be exercised in practice. Here, it is suggested that a set of indicators are devised (similar, in concept, to the Commission's existing media plurality indicators) in order to guide Commission action in this sphere. From an institutional perspective, the EDPS, an independent body tasked with ensuring that the EU institutions respect the right to data protection and data protection legislation, would be well placed to advise on suitable cases where such a non-competition assessment would be required.

\section{CONCLUSION}

The multiple internal and external constraints mapped out in this article indicate that, simply put, data protection law should matter for the application of competition law. This influence extends beyond the Commission respecting data protection law when conducting its investigations or considering it as part of the legal and economic context of markets for personal data. A separate and concurrent application of data protection and competition law is easy to defend when, like in Asnef-Equifax and Facebook/WhatsApp, there is no data protection infringement in sight. However, if ever such an infringement was present, it would

be difficult to ignore. How can competition fail to be harmed if undertakings collude on the conditions offered to acquire personal data, if undertakings take advantage of their dominant position to impose detrimental conditions on consumers, or if mergers that can lead to these effects are cleared? How can the Commission purport to respect its obligation to protect fundamental rights if it turns a blind eye to violations of the right to data protection?

Nevertheless, it is not a foregone conclusion that data protection law will ever matter for competition law, as appearances can be maintained and formalism strictly enforced. If ever cases of collusion, abuse or merger control are decided based on the quality of data use policies, this quality can be assessed without an express reference to data protection law - even though competition law lacks the normative tools and has otherwise been receptive to deferring such competitive assessments to other fields of law. In the same manner, the Commission can continue to deny any responsibility for the effectiveness of the right of data protection by narrowing its inquiry to competitive concerns and pointing to the positive externalities that such enforcement creates for data protection law. 
Keeping data protection and competition law in separate silos has all the advantages of perpetuating the status quo.

Data protection might even welcome that status quo and reject influence over competition law. It is unclear whether, by facilitating the free flow of personal data, the Data Protection Directive sought to encourage markets where personal data itself would be the object of market transactions. Indeed, legal and ethical concerns have been expressed about the commodification of personal data. By not granting individuals property rights over their personal data, but instead merely rights akin to a license, it is arguable that such markets were neither envisaged nor desired at the time when the EU data protection rules were drafted. Applying competition law to those markets might thus serve as official recognition of an unwarranted development. Nevertheless, it seems inevitable that, as with other goods involving personality rights (such as the products of freedom of expression or image rights), the market integration concerns underlying data protection law would attract the application of competition law insofar as both regulate economic activity. There is nonetheless a risk particular to personal data: while the duality of economic value and personal significance of other personality rights is well established, the border between the two concerns still needs to be drawn in the context of the (relatively new) right to data protection. The commodification of data protection might unduly push that border towards economic concerns. However, it is suggested that competition law is more likely to clarify than to harm this definition.

By only applying when there is competition on the quality of data use policies - and backing that analysis with tried and tested economic methods -, competition law can illuminate which aspects of data protection are better left to the market and those which, due to information asymmetries and biases, can only depend on regulation. Meaningful competition on data use policy would undoubtedly benefit consumers. It may be argued that such competition is currently incipient, and that consumers are powerless to implement it. Nevertheless, the digital revolution is slowly but steadily encouraging informed digital users, and competition law must protect their interests. The application of competition law does not preclude adequate ethical regulation of personal data markets by data protection, as well as the control of their negative externalities on non-competitive concerns. Moreover, as data protection law may influence competition law, so too can the reverse happen to the benefit of data protection law: loosely defined concepts such as the 'legitimate interests pursued by the data controller' or the purpose limitation on the treatment of data could benefit from considering the competitive reality facing undertakings, while the validity and scope of consent and the 'the interests or fundamental rights and freedoms of the data subject' could also be adapted to the market power of the data controller. ${ }^{152}$

152 The EDPS also explored this possibility, see Preliminary Opinion of the EDPS (n10) [35]. 
Given this unease regarding the commodification of personal data, it is ironic that competition law scholars may assume that data protection's influence will have the opposite effect: unduly shifting competition law towards noncompetitive concerns. At present DG Competition has been shown little appetite to embrace its positive obligations under the Charter. There is admittedly the danger that such positive obligations could tip the enforcement of competition law towards full-fledged regulation: all aspects of a market, competitive or not, would come within DG Competition's remit. Perhaps the general acceptance of the Commission's sizeable powers in the area of competition law is predicated on their purely economic character, and would quickly become contested if used to pursue other goals. Several safeguards have been discussed in this article which can avert this danger. Nonetheless, critics will inevitably see any concern by the Commission over fundamental rights protection by undertakings as opening the proverbial Pandora's box. These critics might be as late to prevent it as in the myth. The Lisbon Treaty and the Charter have irreversibly changed the obligations which the Commission is subject to in relation to the protection of fundamental rights. As Pandora's box also contained hope, data protection's constraint over competition law may provide the opportunity to best clarify these obligations. 